\title{
Developing a Smart Nursery Application for Monitoring and Babies Care
}

Manar Faleh Alqahtani, Reem Saeed Bashunaym, Norah Mohammed Alotaibi, Razan Zeyad Alkhaldi, Muneerah Alshabanah, Daniah Alrajhi, Mutasem K. Alsmadi and Ibrahim Almarashdeh

Department of Management Information Systems, College of Applied Studies and Community Service, Imam Abdulrahman Bin Faisal University, Dammam, Saudi Arabia

\begin{abstract}
This paper presented a Smart Nursery application for busy parents so that they can ensure the safety and proper care for their babies. This system can show the baby's motion, position and sound through live web-cam camera which is provided by the proposed smart application so that the parents or another responsible person can monitor the baby while away from him or her. This proposed smart application can provide a convenient and easy way for busy parents to take care of their babies. The proposed system was analyzed, design and developed using the Unified Modeling Language (UML), ASP.NET and HTML.
\end{abstract}

Keywords : Baby; Nursery; smart application; and Unified Modeling Language.

\section{INTRODUCTION}

In the last few years, female involvement in the job market in the industrialized countries has significantly increased in society. Then, baby care has become challenging task for a lot of families in the everyday life. always mothers are concerned about the wellness of their babies $[1,2]$.

Currently; the parents have to work and take care of their infants/babies, so more stress and workload are there on parents particularly on mothers. If the smart application is developed to gives continuous updates regarding babies during normal routine or during illness, then it will help significantly the parents to be more productive as they work in a stress-less atmosphere. Furthermore; the smart application will be helpful for the urgent situations that can be rapidly noticed and managed within less time [1-3].

\section{RELATED WORKS}

Hadanty is a website which aims to help parents to find a suitable nursery for their children, figure 1 shows the homepage for Hadanty website. The website provides parents with the following information:

- Information about each nursery, its type, languages available and contact addresses.

- $\quad$ Features available in each nursery and nursery pictures.

- The ability to evaluate nurseries by the website and raise the evaluation on the site.

- Offers and discounts available at nurseries.

- A guide explaining the child's websites and the most important places for children in Egypt.

- Display the advantages and disadvantages of the nursery by parents on the page of the nursery website on Facebook. 


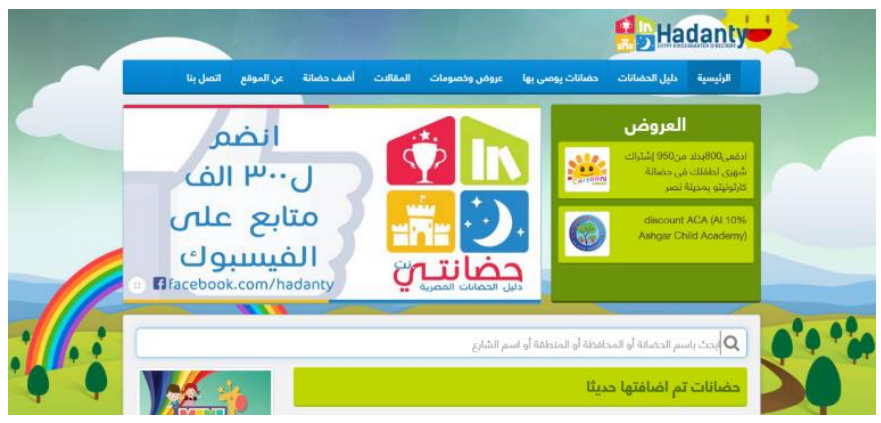

Figure 1: the homepage for Hadanty website.

Jaleesah is a service application and it is a platform that serves mothers and incubators, the aim of the platform is to take care of the child in an environment that is compatible with the growth standards of the child, the application give the ability to choose a babysitter for the child that is close to the parents work and they can learn about the level of the babysitter through the assessments of the other people [4]. Figure 2 shows the homepage for Jaleesah platform.

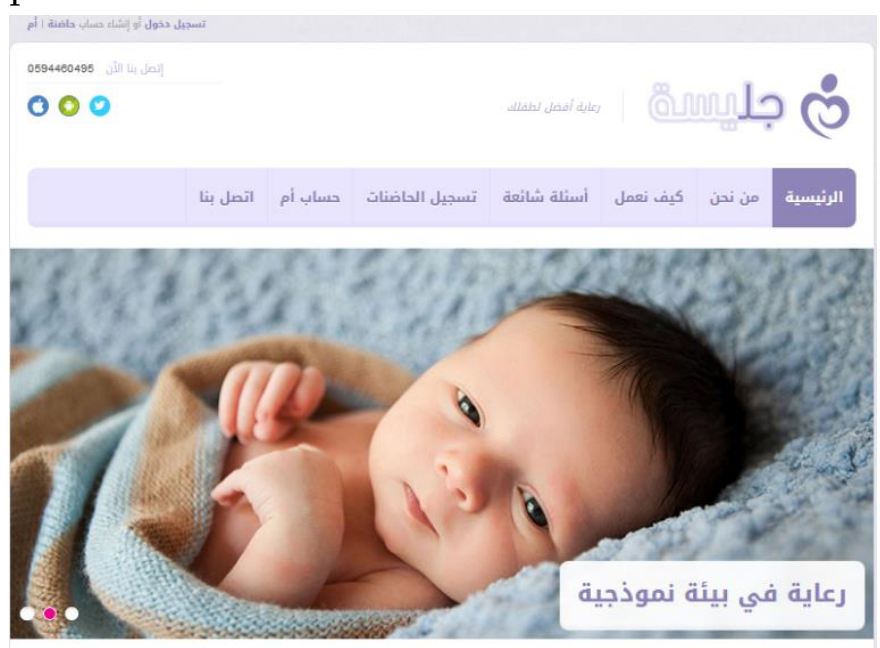

Figure 2: the homepage for Jaleesah platform.

The technological revolution influenced everything [5-82], even the methods of intelligent baby behavior monitoring and healthcare. Nowadays, Artificial Intelligence (AI) algorithms were used widely for solving several difficult problems such as image segmentations [8, 26, 27, 42, 83-87], medical image analysis [28, 32, 88-90], nurse rostering problem [91], Healthcare Monitoring [45, 56], Learning Management System [46], patterns recognition and information retrieval [36, 38], and river flow forecasting [37, 92, 93]. Many researchers have used the AI techniques in monitoring such as smart nursery application $[94,95]$.

\section{METHODOLOGY}

The UML is a method used to provide a standardized notation for defining Models that are Object-Oriented. Though, for applying the UML notation successfully, it has to be employed with an Object-Oriented Analysis and Design (OOAD) method [96-100]. OOAD denotes a set of methodologies that aims to produce business component-based software. The methodology s a summary of system development's life cycle in an object-oriented project, it identifies the tasks and deliverables [101].

Utilizing a combination of UML process and notation, the system development life cycle can be summarized, the reusability of modules can be improved, and the system can be simply maintained.

Traditionally, requirements analysis included finding relevant data and functions that the software system will support. The entity-relationship (ER) diagrams describe the data that will be handled by the system $[102,103]$. The development of object-oriented software uses new design methods, they are supported by computer-aided software engineering tools such as Rational Rose [104].

The UML is a language utilized to visuallize, specify model [103], and for documenting the of an underdevelopment object-Oriented system artifacts. It represents a unification for a number of ideas from various methods. In the system design, UML is used to enhance its maintainability and reusability. Objectoriented analysis methods offer use case, class sequence, , statechart and other modeling notations [102]. UML was employed efficiently in various 
projects for modeling different architectures and requirements [103].

\section{- Use Case Diagram}

The use case diagram is a visualization of a use-case [18, 99, 103, 105], i.e., the smart nursery system interact with three actors namely; Guardian, Supervisor and Technical support. In the proposed system the use case diagram mainly consists of register, login, manage announcement, query on kids files, activate the surveillance camera, deactivate the surveillance camera, profile management, make a conversation, and delete the account. Figure 3 shows the use case diagram for the proposed system.

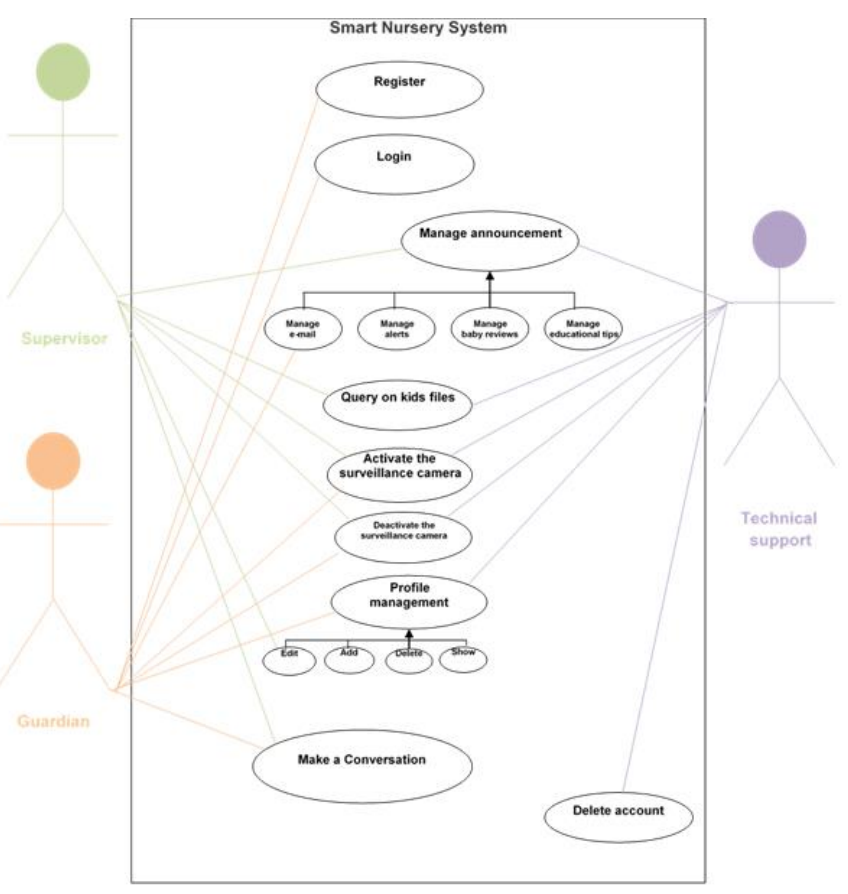

Figure 3: The use case diagram.

\section{- $\quad$ Context Diagram}

A context diagram is a maximum level in a data flow diagram, it comprises a single process to represent the entire system, that establishes the boundaries and context of the modeled system. It demonstrates the information flows between the external entities(i.e. actors) and the system. Typically a context diagram is involved in a requirements document. Figure 4 shows the context diagram for the proposed system.

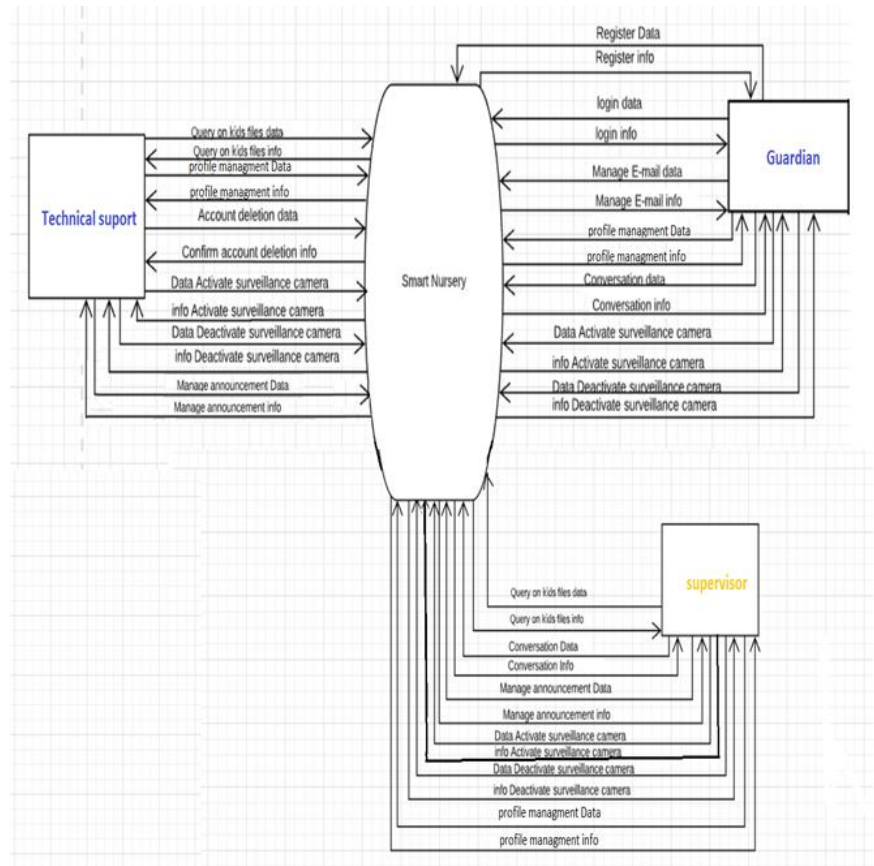

Figure 4: the context diagram.

\section{- Entity Relationship (ER) diagram}

ER diagram shows the relationships of the entity sets stored in a database [106]. Here; an entity is a data component. In other words, the ER diagram demonstrates the logical structure of the proposed system. Figure 5 represents the Entity-Relationship (ER) diagram. 


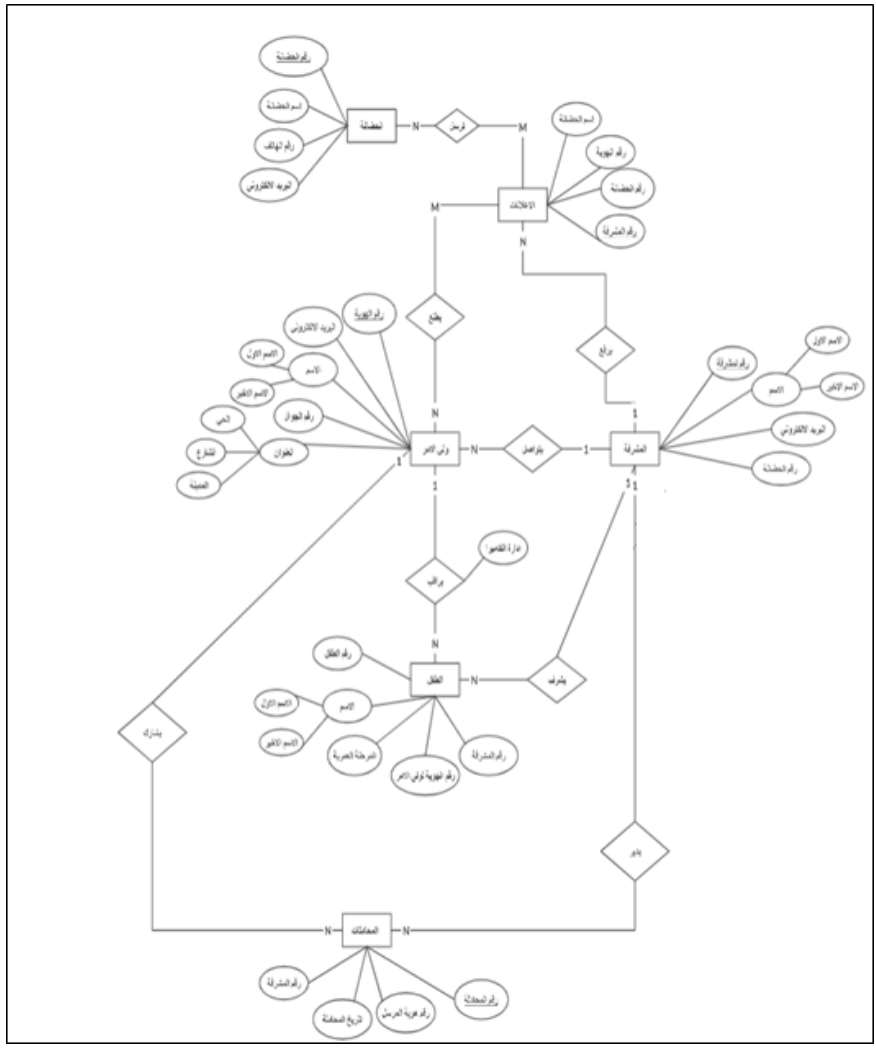

Figure 5: the Entity Relationship (ER) diagram.

\section{Database Testing and Construction}

The database testing is vital for errors detection, these errors may affect the consistency, security, performance, and reliability of the system, also it is crucial for validating system against the requirements specified by the user [106, 107]. SQL was used for database implementation. The tables below are examples of the created tables.

Table 1: Child table

\begin{tabular}{|l|l|c|}
\hline \multicolumn{1}{|c|}{ Column Name } & \multicolumn{1}{c|}{ Data Type } & Allow Nulls \\
8 Child_Number & int & $\square$ \\
Child_FName & nvarchar(20) & $\square$ \\
Child_LName & nvarchar(20) & $\square$ \\
Age_Level & nvarchar(20) & $\square$ \\
Guardian_ID & int & $\square$ \\
Supervisor_ID & int & $\square$ \\
\hline
\end{tabular}

Table 2: Supervisor table

\begin{tabular}{|c|c|c|c|}
\hline \multicolumn{4}{|c|}{ dbo.Supervisor...DATAINURSERY.MDF) $\times$ dbo.Nursery: Tab...DATAINURSERY.MDF) } \\
\hline & Column Name & Data Type & Allow Nulls \\
\hline \multirow[t]{6}{*}{8} & Supervisor_ID & int & $\square$ \\
\hline & Supervisor_FName & nvarchar(20) & $\square$ \\
\hline & Supervisor_LName & nvarchar(20) & $\square$ \\
\hline & Gender & nvarchar(10) & $\square$ \\
\hline & Nursery_ID & int & 曰 \\
\hline & SPassword & nvarchar(10) & 曰 \\
\hline
\end{tabular}

Table 3: Guardian table

\begin{tabular}{|l|l|c|}
\hline \multicolumn{1}{|c|}{ dbo.Guardian: Ta...DATAINURSERY.MDF) } & $\times$ & \multicolumn{1}{c|}{ dbo.Conversation...ATAINURSERY.MDF) } \\
\hline Guardian_ID Name & \multicolumn{1}{c|}{ Data Type } & Allow Nulls \\
Guardian_FName & int & $\square$ \\
Guardian_LName & nvarchar(20) & $\square$ \\
Email & nvarchar(20) & $\square$ \\
Mobile & nvarchar(50) & $\square$ \\
City & nvarchar(15) & $\square$ \\
Street & nvarchar(30) & $\square$ \\
District & nvarchar(30) & $\square$ \\
GPassword & nvarchar(30) & $\square$ \\
\hline
\end{tabular}

\section{Interface Design}

This section demonstrates the artifacts of the proposed work and the implementation step that comes after the system analysis and design. The system analysis and results of configuration are presented. The ASP.NET and HTML were used based on their features which make them suitable for this work. The following figures are examples of designed and implemented interfaces.

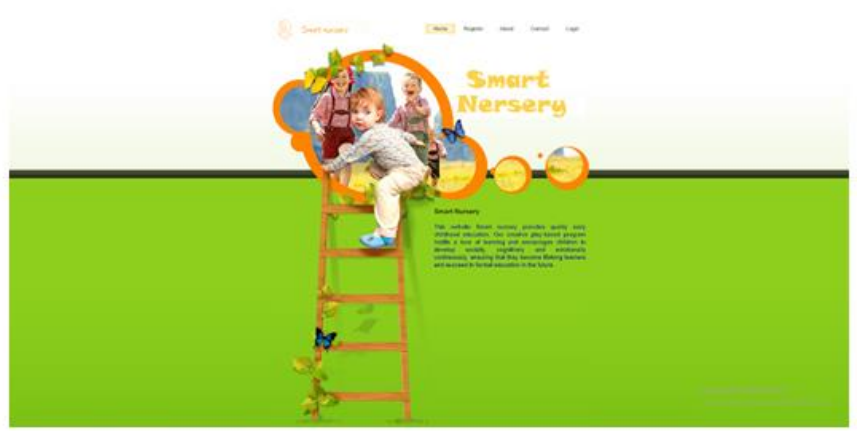

Figure 6: the main interface for the proposed application. 

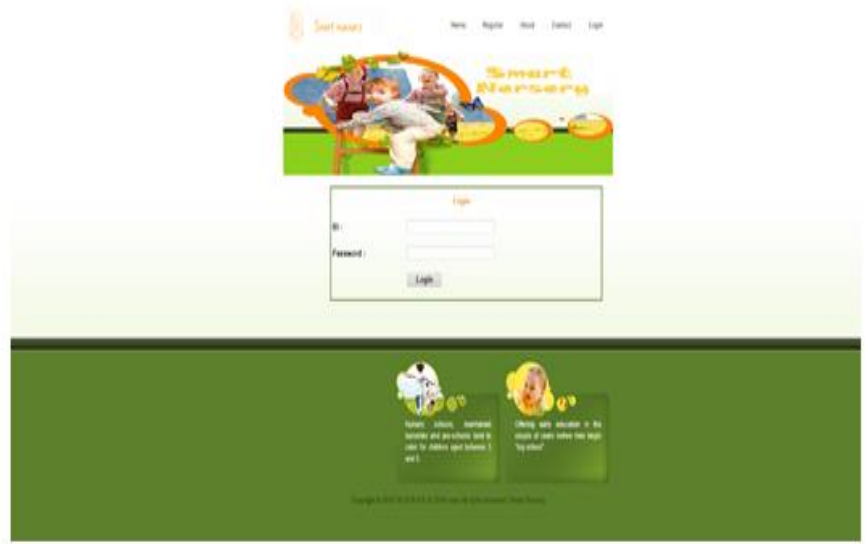

Figure 7: Log in interface
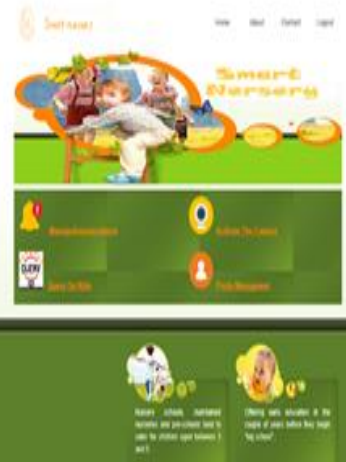

Figure 8: Supervisor interface

\section{RESULTS AND DISCUSSION}

This step highlights the proposed system's usability. the system is evaluated while user satisfaction is guaranteed during this stage. The proposed system was tested by running it on Internet Explorer and Mozilla Firefox using the localhost server. Also for evaluating thee system, 20 students from the College of Applied Studies and Community Service at Imam Abdulrahman Bin Faisal University (IAU) were requested to use the prototype. The students were first briefed on the user's interface and the prototype's usage. After that, the students tested the system and answered the survey questionnaire consisting of 10 items formulated to gauge the level of user satisfaction. The proposed system's usability was also determined. The result, as well as the level of usability of the system according to the feedback provided by 20 students, can be stated in figure 10. As can be seen in figure 10, a high percentage of the users agrees that the proposed system is useful, practical and fulfill the project's main objective.

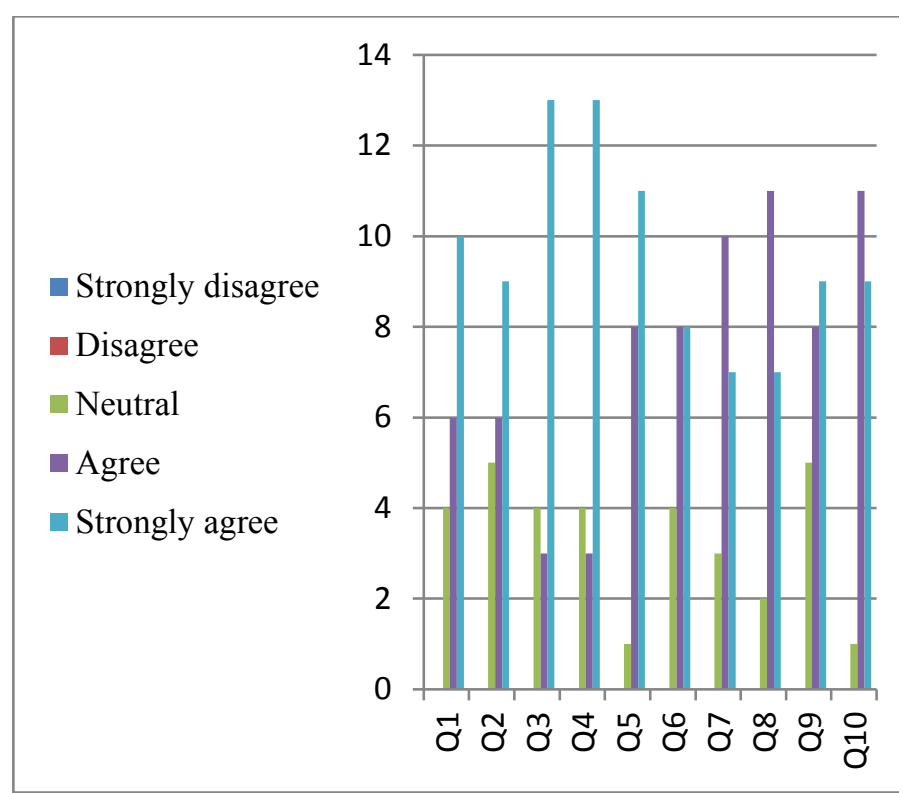

Figure 10: collected data results from the 20 students.

\section{v. CONCLUSION}

This paper presented a Smart Nursery application for busy parents so that they can ensure the safety and proper care for their babies. This system can show the baby's motion, position and sound through live webcam camera which is provided by the proposed smart application so that the parents or another responsible person can monitor the baby while away from him or her. This proposed smart application can provide a convenient and easy way for busy parents to take care of their babies. The proposed system was analyze, design and developed using the Unified Modeling Language (UML), ASP.NET and HTML. 


\section{REFERENCES}

[1]. Patil S P and Mhetre M R. Intelligent Baby Monitoring System. ITSI Transactions on Electrical and Electronics Engineering, 2014, 2(1): 11-16.

[2]. Garcia J and Torres R. Telehealth mobile system. In 2013 Pan American Health Care Exchanges (PAHCE), pp. 1-5.

[3]. Jain N P, Jain P N and Agarkar T P. An Embedded, GSM based, Multi parameter, Realtime Patient Monitoring System and Control. In IEEE Conference publication in World Congress on Information and Communication Technologies.

[4]. Jaleesah.

https://www.jaleesah.com/Default.aspx Access 14-01-2020].

[5]. Almarashdeh I and Alsmadi M K. How to make them use it? Citizens acceptance of Mgovernment. Applied Computing and Informatics.

[6]. Alsmadi M, Omar K, Noah S, Almarashdeh I, Al-Omari S, Sumari P, Al-Taweel S, Husain A, Al-Milli $\mathrm{N}$ and Alsmadi $\mathrm{M}$. Fish recognition based on robust features extraction from size and shape measurements using neural network. Information Technology Journal, 2009, 10(5): 427-434.

[7]. Alsmadi M, Omar K B and Noah S A. Back propagation algorithm: the best algorithm among the multi-layer perceptron algorithm. International Journal of Computer Science and Network Security, 2009, 9(4): 378-383.

[8]. Alsmadi M k, Omar K B and Noah S A. Proposed method to decide the appropriate feature set for fish classification tasks using Artificial Neural Network and Decision Tree. IJCSNS 2009, 9(3): 297-301.

[9]. Alsmadi M K S, Omar K B, Noah S A and Almarashdah I. Fish recognition based on the combination between robust feature selection, image segmentation and geometrical parameter techniques using Artificial Neural Network and Decision Tree. arXiv preprint arXiv:0912.0986, 2009.

[10]. khalil Alsmadi M, Omar K B, Noah S A and Almarashdah I. Performance comparison of multi-layer perceptron (Back Propagation, Delta Rule and Perceptron) algorithms in neural networks. In 2009 IEEE International Advance Computing Conference, pp. 296-299.

[11]. Almarashdeh I A, Sahari N, Zin N A M and Alsmadi M. THE SUCCESS OF LEARNING MANAGEMENT SYSTEM AMONG DISTANCE LEARNERS IN MALAYSIAN UNIVERSITIES. Journal of Theoretical \& Applied Information Technology, 2010, 21(2).

[12]. Almrashdah I A, Sahari N, Zin N A H M and Alsmadi M. Instructors acceptance of distance learning management system. In Information Technology (ITSim), 2010 International Symposium in, pp. 1-6.

[13]. Almrashdah I A, Sahari N, Zin N A H M and Alsmadi M. Distance learners acceptance of learning management system. In Advanced Information Management and Service (IMS), 2010 6th International Conference on, pp. 304309.

[14]. Alsmadi M K, Omar K B and Noah S A. Fish recognition based on robust features extraction from size and shape measurements using backpropagation classifier. International Review on Computers and Software, 2010, 5(4): 489-494.

[15]. Alsmadi M K, Omar K B, Noah S A and Almarashdeh I. Fish recognition based on robust features extraction from color texture measurements using back-propagation classifier. Journal of Theoritical and Applied Information Technology, 2010, 18(1).

[16]. Alsmadi M K, Omar K B, Noah S A and Almarashdeh I. Fish recognition based on 
robust features extraction from size and shape measurements using neural network. Journal of Computer Science, 2010, 6(10): 1088.

[17]. Almarashdeh I A, Sahari N, Zin N A M and Alsmadi M. Acceptance of learning management system: A comparison between distance learners and instructors. Advances in Information Sciences and Service Sciences, 2011, 3(5): 1-9.

[18]. ALMRASHDEH I A, SAHARI N, ZIN N A M and ALSMADI $M$. DISTANCE LEARNING MANAGEMENT SYSTEM REQIUREMENTS FROM STUDENT'S PERSPECTIVE. Journal of Theoretical \& Applied Information Technology, 2011, 24(1).

[19]. Almrashdeh I A, Sahari N, Zin N A M and Alsmadi M. Instructor's success measures of Learning Management System. In Electrical Engineering and Informatics (ICEEI), 2011 International Conference on, pp. 1-7.

[20]. Almrashdeh I A, Sahari N, Zin N A M and Alsmadi M. Requirement analysis for distance learning management system students in Malaysian universities. Journal of Theoretical and Applied Information Technology, 2011, 24(1): 17-27.

[21]. Alsmadi M, Omar K, Noah S and Almarashdeh I. A hybrid memetic algorithm with backpropagation classifier for fish classification based on robust features extraction from PLGF and shape measurements. Information Technology Journal, 2011, 10(5): 944-954.

[22]. Alsmadi M K, Omar K B and Noah S A. Fish classification based on robust features extraction from color signature using backpropagation classifier. Journal of Computer Science, 2011, 7(1): 52.

[23]. Alsmadi M, Omar K and Almarashdeh I. Fish Classification: Fish Classification Using Memetic Algorithms with Back Propagation Classifier. 2012.
[24]. Alsmadi M, Badawi U A and Reffat H E. A High Performance Protocol for Fault Tolerant Distributed Shared Memory (FaTP). Journal of Applied Sciences, 2013, 13: 790-799.

[25]. Alsmadi M, Badawi U A, Reffat H E, Qiang S, Chanjian F, Yuegang $L$ and Peng S. Faults Diagnosis for Automotive Engine Based on Chinin. Journal of Applied Sciences, 2013, 13(23): 5632.

[26]. Badawi U A and Alsmadi M K S. A Hybrid Memetic Algorithm (Genetic Algorithm and Great Deluge Local Search) With BackPropagation Classifier for Fish Recognition International Journal of Computer Science Issues, 2013, 10(2): 348-356.

[27]. Thalji $\mathrm{Z}$ and Alsmadi M. Iris Recognition using robust algorithm for eyelid, eyelash and shadow avoiding. World Applied Sciences Journal, 2013, 25(6): 858-865.

[28]. Alsmadi M K. A hybrid firefly algorithm with fuzzy-C mean algorithm for MRI brain segmentation. American Journal of Applied Sciences, 2014, 11(9): 1676-1691.

[29]. Alsmadi M K, Badawi U A and Moharram H M. SERVER FAILURES ENABLED JAVASPACES SERVICE. Journal of Computer Science, 2014, 10(4): 671-679.

[30]. Badawi U A and Alsmadi M K. A GENERAL FISH CLASSIFICATION METHODOLOGY USING META-HEURISTIC ALGORITHM WITH BACK PROPAGATION CLASSIFIER. Journal of Theoretical \& Applied Information Technology, 2014, 66(3): 803-812.

[31]. Al Smadi A M, Alsmadi M K, Al Bazar H, Alrashed S and Al Smadi B S. Accessing Social Network Sites Using Work Smartphone for Face Recognition and Authentication. Research Journal of Applied Sciences, Engineering and Technology, 2015, 11(1): 5662. 
[32]. Alsmadi M K. MRI brain segmentation using a hybrid artificial bee colony algorithm with fuzzy-c mean algorithm. Journal of Applied Sciences, 2015, 15(1): 100.

[33]. HADDAD F, ALFARO J and ALSMADI M K. HOTELLING'S T T ${ }^{2} \quad$ CHARTS USING WINSORIZED MODIFIED ONE STEP MESTIMATOR FOR INDIVIDUAL NON NORMAL DATA. Journal of Theoretical \& Applied Information Technology, 2015, 72(2): 215-226.

[34]. Almarashdeh I and Alsmadi M. Investigating the acceptance of technology in distance learning program. In 2016 International Conference on Information Science and Communications Technologies (ICISCT), 2-4 Nov. 2016, pp. 1-5.

[35]. Almarashdeh I and Alsmadi M. Heuristic evaluation of mobile government portal services: An experts' review. In Internet Technology and Secured Transactions (ICITST), 2016 11th International Conference for, pp. 427-431.

[36]. Alsmadi M. Facial recognition under expression variations. Int. Arab J. Inf. Technol., 2016, 13(1A): 133-141.

[37]. Alsmadi M K. Forecasting River Flow in the USA Using a Hybrid Metaheuristic Algorithm with Back-Propagation Algorithm. Scientific Journal of King Faisal University (Basic and Applied Sciences), 2017, 18(1): 13-24.

[38]. Alsmadi M K. Query-sensitive similarity measure for content-based image retrieval using meta-heuristic algorithm. Journal of King Saud University - Computer and Information Sciences, 2017.

[39]. Alsmadi M K. An efficient similarity measure for content based image retrieval using memetic algorithm. Egyptian Journal of Basic and Applied Sciences, 2017, 4(2): 112-122.
[40]. Alsmadi M K and Badawi U A. Pattern matching in Rotated Images Using Genetic Algorithm. Journal of King Abdulaziz University Computing and Information 2017, 5: 53 - 59 .

[41]. Alsmadi M K, Hamed A Y, Badawi U A, Almarashdeh I, Salah A, Farag T H, Hassan W, Jaradat G, Alomari Y M and Alsmadi H M. FACE IMAGE RECOGNITION BASED ON PARTIAL FACE MATCHING USING GENETIC ALGORITHM. SUST Journal of Engineering and Computer Sciences (JECS), 2017, 18(1): 51-61.

[42]. Farag $\mathrm{T} H$, Hassan $\mathrm{W} A$, Ayad $\mathrm{H}$ A, AlBahussain A S, Badawi U A and Alsmadi M K. Extended Absolute Fuzzy Connectedness Segmentation Algorithm Utilizing Region and Boundary-Based Information. Arabian Journal for Science and Engineering, 2017: 1-11.

[43]. Aldaej R, Alfowzan L, Alhashem R, Alsmadi M K, Al-Marashdeh I, Badawi U A, Alshabanah M, Alrajhi D and Tayfour M. Analyzing, Designing and Implementing a Web-Based Auction online System. International Journal of Applied Engineering Research, 2018, 13(10): 8005-8013.

[44]. Almaimoni H, Altuwaijri N, Asiry F, Aldossary S, Alsmadi M, Al-Marashdeh I, Badawi U A, Alshabanah $\mathrm{M}$ and Alrajhi D. Developing and Implementing WEB-based Online Destination Information Management System for Tourism. International Journal of Applied Engineering Research, 2018, 13(10): 7541-7550.

[45]. Almarashdeh i, Alsmadi M K, Farag T, Albahussain A S, Badawi U A, Altuwaijri N, Almaimoni H, Asiry F, Alowaid S, Alshabanah M, Alrajhi D, Fraihet A A and Jaradat G. RealTime Elderly Healthcare Monitoring Expert System Using Wireless Sensor Network International Journal of Applied Engineering Research, 2018, 13(6): 3517-3523. 
[46]. Almarashdeh I, Alsmadi M K, Jaradat G, Althunibat A, Albahussain S A, Qawqzeh Y, Badawi U A, Farag T and Eldaw K E. Looking Inside and Outside the System: Examining the Factors Influencing Distance Learners Satisfaction in Learning Management System Journal of Computer Science, 2018.

[47]. Almarashdeh I, Eldaw K E, AlSmadi M, Badawi U, Haddad F, Abdelkader O A, Jaradat G, Alkhaldi A and Qawqzeh Y. Search Convenience and Access Convenience: The Difference Between Website Shopping and Mobile Shopping. In International Conference on Soft Computing and Pattern Recognition, pp. 33-42.

[48]. Al-Marashdeh I, Jaradat G M, Ayob M, AbuAl-Aish A and Alsmadi M. An Elite Pool-Based Big Bang-Big Crunch Metaheuristic for Data Clustering. Journal of Computer Science, 2018, 14(12): 1611-1626.

[49]. Alsmadi M K. Apparatus and method for lesions segmentation. 2018.

[50]. Alsmadi M K. Facial expression recognition. 2018.

[51]. Alsmadi M K. A hybrid Fuzzy C-Means and Neutrosophic for jaw lesions segmentation. Ain Shams Engineering Journal, 2018, 9(4): 697706.

[52]. Alsmadi M K. Query-sensitive similarity measure for content-based image retrieval using meta-heuristic algorithm. Journal of King Saud University-Computer and Information Sciences, 2018, 30(3): 373-381.

[53]. Alsubaie N, Althaqafi N, Alradwan E, AlHazza F, Alsmadi M, Al-Marashdeh I, Badawi U A, Alshabanah M, Alrajhi D, Alsmadi S and Tayfour M. Analyzing and Implementing an Online Metro Reservation System. International Journal of Applied Engineering Research, 2018, 13(11): 9198-9206.
[54]. Daniyah Alkhaldi D A, Hajer Aldossary, Mutasem k. Alsmadi, Ibrahim Al-Marashdeh, Usama A Badawi, Muneerah Alshabanah, Daniah Alrajhi. Developing and Implementing Web-based Online University Facilities Reservation System. International Journal of Applied Engineering Research, 2018, 13(9): 6700-6708.

[55]. Haddad F and Alsmadi M K. Improvement of The Hotelling's T2 Charts Using Robust Location Winsorized One Step M-Estimator (WMOM). Journal of Mathematics (ISSN 10162526), 2018, 50(1): 97-112.

[56]. Rasmi M, Alazzam M B, Alsmadi M K, Almarashdeh I A, Alkhasawneh R A and Alsmadi S. Healthcare professionals' acceptance Electronic Health Records system: Critical literature review (Jordan case study). International Journal of Healthcare Management, 2018: 1-13.

[57]. Abbas A A, Alzayer K, Alkhaldi A, Alsmadi M k, Alshabanah M, Alrajhi D, Almarashdeh I and Tayfour M. Analyzing and Implementinga System For Reporting, Follow Up and Resolving of Complaints. International Research Journal of Engineering and Technology, 2019, 6(1): 1833-1842.

[58]. Ahmed A O, Ahmed M E, Mekebbaty M M E, Osman A M, Mohamed A S, Alhaj G M and Shidwan O S. Impact of Change Characteristics in Planning for Future Professional Career. International Journal of Applied Engineering Research, 2019, 14(20): 3869-3878.

[59]. Aldossary S, Althawadi A, Almotairy M, Alsmadi M k, Alrajhi D, Alshabanah M, AlMarashdeh I, Tayfour M and Aljamaeen R. ANALYZING, DESIGNING AND IMPLEMENTING A WEB-BASED COMMAND CENTER SYSTEM. International Research Journal of Engineering and Technology, 2019, 6(1): 1008-1019. 
[60]. Al-Ghamdi A, Al Harbi D, Alarfaj N, Al Hajri A, Almarashdeh I, Alsmadi M, Alshabanah M and Alrajhi D. Developing and Implementing a Web-Based Platform for Skills and Knowledge Exchange. Int J Sci Res Sci Technol, 2019, 6(3): 562-573.

[61]. Al-Ghamdi A, Harbi D A, Alarfaj N, Hajri B A, Almarashdeh I, Alsmadi M k, Alshabanah M and Alrajhi D. Developing and Implementing a Web-Based Platform for Skills and Knowledge Exchange. International Journal of Scientific Research in Science and Technology (IJSRST), 2019, 6(3).

[62]. Alhafi R, Almutairi S, Alsultan N, Alsmadi M $\mathrm{K}$, Alshabanah M, Alrajhi D and Almarashdeh I. E-Payment and Transactions using $\mathrm{QR}$ Codes. 2019.

[63]. Alharbi S, Altamimi A, Al-Qahtani F, Aljofi B, Alsmadi M, Alshabanah M, Alrajhi D and Almarashdeh I. Analyzing and Implementing a Mobile Reminder System for Alzheimer's Patients. International Research Journal of Engineering and Technology, 2019, 6(2): 1-11.

[64]. Ali S A S, Eldaw K E H I, Alsmadi M K and Almarashdeh I. Determinants of deposit of commercial banks in Sudan: an empirical investigation (1970-2012). International Journal of Electronic Finance, 2019, 9(3): 230255.

[65]. Almarashdeh I, Jaradat G, Abuhamdah A, Alsmadi M, Alazzam M B, Alkhasawneh R and Awawdeh I. The Difference Between Shopping Online Using Mobile Apps and Website Shopping: A Case Study of Service Convenience. International Journal of Computer Information Systems and Industrial Management Applications, 2019, 11: 151-160.

[66]. Al-Omairi D S, AlNasheri W H, Al-Qarni W Y, Almarashdeh I, Alsmadi M k, Alshabanah M and Alrajhi D. Developing and Implementing A Web-Based Recycling System For Protecting
The Green Environment. International Journal of Software Engineering and Applications, 2019, 10(3): 59-72.

[67]. Alomari E, Alshammry M, Alhamil S, Alsmadi M, Alshabanah M, Alrajhi D, Almarashdeh I and Eljawad L. Analyzing, Designing and Implementing a Consulting Company for Management Information Systems. International Research Journal of Engineering and Technology, 2019, 6(2): 422-432.

[68]. Alomari E, Alshammry M, Alhamil S, Alsmadi M k, Alshabanah M, Alrajhi D, Almarashdeh I and Eljawad L. Analyzing, Designing and Implementing a Consulting Company for Management Information Systems. International Research Journal of Engineering and Technology 2019, 6(2): 422-432.

[69]. Al-Smadi A M, Alsmadi M K, Baareh A, Almarashdeh I, Abouelmagd $\mathrm{H}$ and Ahmed $\mathrm{O}$ S S. Emergent situations for smart cities: a survey. International Journal of Electrical \& Computer Engineering (2088-8708), 2019, 9(6): 4777-4787.

[70]. Alsmadi M K. Hybrid Genetic Algorithm with Tabu Search with Back-Propagation Algorithm for Fish Classification: Determining the Appropriate Feature Set. International Journal of Applied Engineering Research, 2019, 14(23): 4387-4396.

[71]. Alsmadi M K, Tayfour M, Alkhasawneh R A, Badawi U, Almarashdeh I and Haddad F. Robust feature extraction methods for general fish classification. International Journal of Electrical \& Computer Engineering (20888708), 2019, 9(6): 5192-5204.

[72]. Al-Theeb R, Al-Tami H, Al-Johani H, AlMutairi A, Al-Marashdeh I, Alsmadi M K, Alshabanah $\mathrm{M}$ and Alrajhi D. Developing and Implementing A System for Shipping Companies Comparison. IJSRST 2019, 6(4). 
[73]. Alzamel H, Alshabanah $\mathrm{M}$ and Alsmadi M. Point of Sale (POS) Network with Embedded Fingerprint Biometric Authentication. International Journal of Scientific Research in Science and Technology (IJSRST), 2019, 6(5): 95-111.

[74]. Eljawad L, Aljamaeen R, Alsmadi M K, AlMarashdeh I, Abouelmagd H, Alsmadi S, Haddad F, Alkhasawneh R A, Alzughoul M and Alazzam M B. Arabic Voice Recognition Using Fuzzy Logic and Neural Network. International Journal of Applied Engineering Research, 2019, 14(3): 651-662.

[75]. Haddad F, Alsmadi M K, Badawi U, Farag T, Alkhasawneh R, Almarashdeh I and Hassan W. Bivariate modified hotelling's $\mathrm{T}^{2}$ charts using bootstrap data. International Journal of Electrical \& Computer Engineering (20888708), 2019, 9(6): 4721-4727.

[76]. Mohammed A S S, Alhaj G M, Osman A M and Ahmed A O. The Effectiveness of the Decision Making of the Saudi Arabian Universities Applied Colleges' Faculties Boards and Departmental Councils. International Journal of Applied Engineering Research, 2019, 14(23): 4221-4227.

[77]. Osman A M, Ahmed A O, Eltahir M N, Mohamed A S, Shidwan O S and Ghada M. Investigating the Causes of inflation in Saudi Arabia: An Application of Autoregressive Distributed Lag (ARDL) Model. International Journal of Applied Engineering Research, 2019, 14(21): 3980-3986.

[78]. Qawqzeh Y K, Otoom M M, Al-Fayez F, Almarashdeh I, Alsmadi $\mathrm{M}$ and Jaradat G. A Proposed Decision Tree Classifier for Atherosclerosis Prediction and Classification. IJCSNS, 2019, 19(12): 197.

[79]. Sheikh R A, Al-Assami R, Albahr M, Suhaibani M A, Alsmadi M k, Alshabanah M, Alrajhi D, Al-Marashdeh I, Alsmadi S, Abouelmagd H and Tayfour M. Developing and Implementing a Barcode Based Student Attendance System. International Research Journal of Engineering and Technology, 2019, 6(1): 497-506.

[80]. Alsmadi M K. Content-Based Image Retrieval Using Color, Shape and Texture Descriptors and Features. Arabian Journal for Science and Engineering, 2020: 1-14.

[81]. Alzaqebah M A, Alrefai N, Ahmed E, Jawarneh $S$ and Alsmadi M. Neighborhood search methods with Moth Optimization algorithm as a wrapper method for feature selection problems. International Journal of Electrical \& Computer Engineering, 2020, 10(4).

[82]. Qawqzeh Y K, Jaradat G, AlYousef A, AbuHamdah A, Almarashdeh I, Alsmadi M, Tayfour M, Shaker K and Haddad F. Applying the Big Bang-Big Crunch Metaheuristic to Large-sized Operational Problems. International Journal of Electrical and Computer Engineering, 2020, 10(3): 24842502.

[83]. Alsmadi M K. A hybrid Fuzzy C-Means and Neutrosophic for jaw lesions segmentation. Ain Shams Engineering Journal.

[84]. $\mathrm{M} \mathrm{A}, \mathrm{K} \mathrm{O}$ and $\mathrm{S}$ N. Back Propagation Algorithm : The Best Algorithm Among the Multi-layer Perceptron Algorithm. International Journal of Computer Science and Network Security, 2009, 9(9): 378-383.

[85]. Alsmadi M k, Omar K B, Noah S A and Almarashdah I. Performance Comparison of Multi-layer Perceptron (Back Propagation, Delta Rule and Perceptron) algorithms in Neural Networks. In 2009 IEEE International Advance Computing Conference, 6-7 March 2009, pp. 296-299.

[86]. Sharma M, Purohit G and Mukherjee S. Information Retrieves from Brain MRI Images for Tumor Detection Using Hybrid Technique K-means and Artificial Neural Network 
(KMANN). Networking Communication and Data Knowledge Engineering. Springer, 2018, pp. 145-157.

[87]. Gao Y, Li X, Dong M and Li H-p. An enhanced artificial bee colony optimizer and its application to multi-level threshold image segmentation. Journal of Central South University, 2018, 25(1): 107-120.

[88]. Alsmadi M K. A hybrid Fuzzy C-Means and Neutrosophic for jaw lesions segmentation. Ain Shams Engineering Journal, 2017.

[89]. Park S H and Han K. Methodologic Guide for Evaluating Clinical Performance and Effect of Artificial Intelligence Technology for Medical Diagnosis and Prediction. Radiology, 2018: 171920.

[90]. Kermany D S, Goldbaum M, Cai W, Valentim C C, Liang H, Baxter S L, McKeown A, Yang G, $\mathrm{Wu} \mathrm{X}$ and Yan $\mathrm{F}$. Identifying Medical Diagnoses and Treatable Diseases by ImageBased Deep Learning. Cell, 2018, 172(5): 11221131. e1129.

[91]. Jaradat G M, Al-Badareen A, Ayob M, AlSmadi M, Al-Marashdeh I, Ash-Shuqran M and Al-Odat E. Hybrid Elitist-Ant System for Nurse-Rostering Problem. Journal of King Saud University-Computer and Information Sciences, 2018.

[92]. Adeyemo J, Oyebode O and Stretch D. River Flow Forecasting Using an Improved Artificial Neural Network. EVOLVE-A Bridge between Probability, Set Oriented Numerics, and Evolutionary Computation VI. Springer, 2018, pp. 179-193.

[93]. Ahani A, Shourian $M$ and Rad $P$ R. Performance Assessment of the Linear, Nonlinear and Nonparametric Data Driven Models in River Flow Forecasting. Water Resources Management, 2018: 1-17.
[94]. Owlet. The smart nursery of the future. https://owletcare.com.au/blogs/blog/the-smartnursery-of-the-future . Access 13-12-2019].

[95]. Hussain T, Muhammad K, Khan S, Ullah A, Lee $\mathrm{M} \mathrm{Y}$ and Baik S W. Intelligent Baby Behavior Monitoring using Embedded Vision in IoT for Smart Healthcare Centers. Journal of Artificial Intelligence and Systems. J. Artif. Intell. Syst, 2019, 1(15): 2019.

[96]. Fontoura M, Pree W and Rumpe B. UML-F: A modeling language for object-oriented frameworks. In European Conference on Object-Oriented Programming, pp. 63-82.

[97]. Teixeira 1, Xambre A R, Figueiredo J and Alvelos H. Analysis and design of a project management information system: practical case in a consulting company. In CENTERIS/ProjMAN/HCis, pp. 171-178.

[98]. Almarashdeh I, Elias N F, Sahari N and Zain N A M. Development of an interactive learning management system for malaysian distance learning institutions. . Middle East Journal of Scientific Research, 14(11), 10.5829/idosi.mejsr.2013.14.11.2339, 2013, 14(11): 1471-1479.

[99]. Rajagopal D and Thilakavalli K. A Study: UML for OOA and OOD. International Journal of Knowledge Content Development \& Technology, 2017, 7(2): 5-20.

[100]. Torchiano M, Scanniello G, Ricca F, Reggio G and Leotta M. Do UML object diagrams affect design comprehensibility? Results from a family of four controlled experiments. Journal of Visual Languages \& Computing, 2017, 41: 10-21.

[101]. Dennis A, Wixom B H and Tegarden D. Systems analysis and design: An objectoriented approach with UML. 2015.

[102]. Dick J, Hull E and Jackson K. Requirements engineering. 2017. 
[103]. Bello S I, Bello R O, Babatunde A O, Olugbebi $\mathrm{M}$ and Bello B O. A University Examination Web Application Based on Linear-Sequential Life Cycle Model. 2017.

[104]. Sheldon F T, Jerath K, Kwon Y-J and Baik YW. Case study: Implementing a web based auction system using UML and componentbased programming. In Computer Software and Applications Conference, 2002. COMPSAC 2002. Proceedings. 26th Annual International, pp. 211-216.

[105]. Almarashde I, Althunibat A and Fazidah El N. Developing a Mobile Portal Prototype for Egovernment Services. Journal of Applied Sciences, 2014, 14: 791-797.

[106]. Onuiri E E, Omoroje H C, Ntima C G and Omotunde A A. Intelligent Tourism Management System. American Scientific Research Journal for Engineering, Technology, and Sciences (ASRJETS), 2016, 18(1): 304-315.

[107]. Begg C and Connolly T. Database systems: A practical guide to design, implementation, and management. 2002.

\section{Cite this article as :}

Manar Faleh Alqahtani, Reem Saeed Bashunaym, Norah Mohammed Alotaibi, Razan Zeyad Alkhaldi, Muneerah Alshabanah, Daniah Alrajhi, Mutasem K. Alsmadi, Ibrahim Almarashdeh, "Developing a Smart Nursery Application for Monitoring and Babies Care", International Journal of Scientific Research in Science and Technology (IJSRST), Online ISSN : 2395-602X, Print ISSN : 2395-6011, Volume 7 Issue 2, pp. 156-168, March-April 2020. Available at doi : https://doi.org/10.32628/IJSRST207161 Journal URL : http://ijsrst.com/IJSRST207161 